\title{
Response of Oxypetalum caeruleum to Irradiance, Temperature, and Photoperiod
}

\author{
A.M. Armitage \\ Department of Horticulture, University of Georgia, Athens, GA 30602 \\ N.G. Seager, I.J. Warrington, and D.H. Greer \\ Plant Physiology Division, Department of Scientific and Industrial Research, Private Bag, \\ Palmerston North, New Zealand
}

\author{
J. Reyngoud \\ Department of Horticulture, Massey University, Palmerston North, New Zealand
}

Additional index words. photosynthetic photon flux, tweedia, net photosynthesis, vase life, postharvest, silver thiosulfate

\begin{abstract}
Incremental increases in temperature from 14 to 22 to $30 \mathrm{C}$ resulted in linear increases in stem length and node number and decreases in stem diameter and stem strength of Oxypetalum caeruleum (D. Don.) Decne. Higher temperatures also resulted in additional flower abortion, reduced time to flowering, and fewer flowering stems per inflorescence. Reduction in the photosynthetic photon flux (PPF) from 695 to $315 \mu \mathrm{mol} \cdot \mathrm{s}^{-1} \cdot \mathrm{m}^{-2}$ had similar effects as increasing the temperature on vegetative characteristics, but had little effect on reproductive ones. The rate of stem elongation was greatest at low PPF for all temperatures and at high temperature for all PPF treatments. Net photosynthesis rose between 14 and $22 \mathrm{C}$ and declined at $30 \mathrm{C}$ for all PPF treatments. Long photoperiods (12 or 14 hours) resulted in longer internodes, longer stems, and more flowers per cyme than short photoperiods $(8$ or 10 hours), but photoperiod had little effect on flowering time. Treatments to reduce latex coagulant and silver thiosulfate treatments had no significant effect on vase life.
\end{abstract}

Oxypetalum caeruleum (tweedia) belongs to Asclepiadaceae and bears light-green opposite leaves and cymose panicles, each cyme consisting of three to five five-petaled light-blue flowers. The species is native to Brazil and Uruguay (Bailey, 1951) and grown in the United. States, Holland, New Zealand, and Australia as a specialty cut flower crop. Other important ornamental crops in Asclepiadaceae are Asclepias tuberosa L., Stephanotis floribunda Brongn., and Hoya carnosa R. Br. Asclepias is dayneutral with respect to flowering, but long days promote shoot extension and leaf production (Lyons, 1985) and inhibit lateral branching (Lyons and Booze, 1983). Stephanotis is a long-day plant for flower initiation, with an optimum of $21 \mathrm{C}$ for flowering (Kofranek and Criley, 1983), and Hoya has a minimum of 15C for flowering (Post, 1955). Little literature is available on the response of Oxypetalum to light and temperature, although Post (1955) suggested a minimum of $18 \mathrm{C}$ for best vegetative growth. Similarly, no studies have been conducted to determine photosynthetic characteristics of the species.

Cut stems of Oxypetalum exude a milky latex-like sap. Halevy and Mayak (1981) noted that many flowers with milky latex tended to have short vase lives, which was generally attributed to latex plugging of the conducting vessels. Isopropyl alcohol (Freyermuth et al., 1984; Gordon et al., 1986), a boiling water dip (Salinger, 1985; Stirling, 1950; Systems, 1966), or a warm water dip (45C) for 15 min (Salinger, 1985) has been proposed to eliminate the exudate. Vase life of numerous species has been extended with silver thiosulphate (STS) (Farnham et al., 1981; Veen and van de Geijen, 1978); proprietary preservative solutions, mainly those containing sucrose and biocides, are also commonly employed. The objectives of this work

Received for publication 6 Nov. 1989. We thank W.A. Laing, Plant Physiology Div., Dept. of Scientific and Industrial Research (DSIR), Palmerston North, New Zealand, for his help with the photosynthetic analyses and members of the DSIR Climate Laboratory Technical Systems Group for maintenance of the controlled-environment rooms. The cost of publishing this paper was defrayed in part by the payment of page charges. Under postal regulations, this paper therefore must be hereby marked advertisement solely to indicate this fact. were to 1) demonstrate the effects of photosynthetic photon flux (PPF) on flowering, quality of flowering stems, and photosynthesis of tweedia, 2) demonstrate the effects of temperature and photoperiod on growth and flowering, and 3) evaluate the vase life of the cut flower and determine if vase life could be extended by selected conditioning treatments.

\section{Materials and Methods}

Light-temperature studies. Rooted cuttings were received from Gunderson Nurseries, Otaki, New Zealand, and all stems were immediately pinched to two nodes to ensure removal of reproductive tissue. Seventy-two uniform plants growing in 1.2-litercapacity pots containing 5 peat : 3 pumice (v/v) growing medium were randomly placed in nine light-temperature combinations. Plants were grown in walk-in controlled-environment (CE) rooms at the Dept. of Scientific and Industrial Research Climate Laboratory, Palmerston North, New Zealand. Temperatures were constant at 30,22 , or $14 \pm 0.5 \mathrm{C}$. A constant vapor pressure deficit of $0.45 \mathrm{kPa}$ was maintained resulting in relative humidities of $90 \%, 83 \%$, or $72 \% \pm 5 \%$, respectively. Lighting over the 12-hr photoperiod was provided by four 1000-W highpressure multivapor lamps (Sylvania "Metalarc") and four 1000W Philips quartz halogen lamps separated from the chamber by a plate glass and water thermal barrier. The PPF at pot surface height was $695 \pm 20 \mu \mathrm{mol} \cdot \mathrm{s}^{-1} \cdot \mathrm{m}^{-2}$ (high light). Use of woven Saran cloth of $=35 \%$ density provided a PPF of $450 \pm 10$ $\mu \mathrm{mol} \cdot \mathrm{s}^{-1} \cdot \mathrm{m}^{-2}$ (medium light), and cloth of $55 \%$ density, a PPF of $315 \pm 8 \mu \mathrm{mol} \cdot \mathrm{s}^{-1} \cdot \mathrm{m}^{-2}$ (low light). Each density of Saran cloth was suspended over one PPF treatment in each of the growth rooms. Additional information on room design, temperature inputs, humidity control, and lighting design has been described previously (DSIR Climate Laboratory, 1981; Barrington and Kanemasu, 1983). Plants were watered with 100 $\mathrm{ml}$ of complete mineral nutrient solution (half-strength Hoagland's A) (Hoagland and Arnon, 1938) three times daily from an automated irrigation system.

Stem length and number of nodes were recorded once a week on four randomly selected plants at the beginning of the exper- 
iment until anthesis. First anthesis of all stems was recorded and stems were harvested when at least one flower on six cymes was open. At harvest, the number of stems, stem length, stem diameter, number of flowers per cyme, and nodes without flowers or with aborted flowers were recorded on all plants within a treatment. A stem is similar to a homogeneous cylinder of any material. The strength (critical load) of a cylinder increases by the fourth power of the radius. Therefore, even a small increase in the cross-section area of a plant axis would result in a substantial increase in its strength (Goeschl et al., 1966). Similarly, an increase in stem length, given the same diameter, results in stems with less ability to remain erect. Stem diameter was divided by stem length to provide an estimate of stem strength or critical load the stem may support.

Photosynthetic light response curves were determined for $O$. caeruleum growing at $22 \mathrm{C}$ and high PPF. Flux density was varied using neutral-density filters. Net photosynthesis (Pn) was measured on newly expanded mature leaves in an open gas exchange system. The $\mathrm{CO}_{2}$ partial pressure was monitored in an infrared gas analyzer (LCA-2; ADC, Hoddesdon, U. K.) and was between 0.33 and 0.35 $\mathrm{kPa}$. Leaf temperature and leaf-to-air water vapor difference were uncontrolled, but were within $\mathrm{IC}$ and $5 \% \mathrm{RH}$, respectively, of the ambient conditions. Leaf area of selected leaves was measured with a LI-COR model 1800 leaf area meter (LI-COR, Lincoln, Neb.). Trend analysis $(P=0.05)$ was conducted on main treatments for all characteristics.

Photoperiod studies. Seven plants, potted and pinched similarly as for the previous study, were randomly placed in reachin growth cabinets maintained at constant $22 \pm 2 \mathrm{C}$ and at photoperiods of either $8,10,12$, or $14 \mathrm{hr}$. Light was provided by high-pressure mercury vapor : incandescent lamps (=2:1 installed wattage ratio). Plants were raised or lowered as necessary to receive a similar daily photon flux integral at all photoperiods. Plants received 14.4, ' $13.7,15.3$, and $14.6 \mathrm{~mol} \cdot \mathrm{s}^{-1} \cdot \mathrm{m}^{-2}$ in the 8-, 10-, 12-, and 14-hr treatments, respectively. All plants were irrigated with half-strength modified Hoagland's A nutrient solution as required. Data similar to those described in the light $\mathrm{x}$ temperature studies, except stem growth rates and Pn, were collected on all plants. Trend analysis $(P=0.05)$ was conducted on photoperiod treatments for all criteria.

Postharvest studies. Stems with open flowers on about six cymes were harvested, recut, and placed in $\mathrm{O}-, 2-$, 4-, or 8-mM solutions of STS (four single-stem replications) or in latex coagulant (eight single-stem replications). Treatment time was 20 rein, except with, isopropyl alcohol, which was $10 \mathrm{~min}$. The coagulant treatments were distilled water, boiling water, isopropyl alcohol, methylated spirits, or warm water (45 C). All solutions were made up in distilled water. Flower vase life was assessed in a standard holding room (Reid and Kofranek, 1980), and the number of days the inflorescences were acceptable was determined for each treatment. Senescence of an individual flower was deemed to have occurred when the petals changed from blue to pink. Vase life measurement was terminated either when more than half of the flowers in an inflorescence had senesced, wilting of the inflorescence occurred, or when the leaves became chlorotic. Analysis of variance $(P=0.05)$ was conducted on vase life measurements.

\section{Results and Discussion}

\section{Light $x$ temperature}

Vegetative characteristics. As there were no significant temperature $\mathrm{x}$ PPF interactions for any vegetative criterion mea- sured, only the results from the main treatments are presented. The reduction in temperature from 30 to $14 \mathrm{C}$ resulted in a linear decrease in stem length and number of nodes and a linear increase in stem diameter and stem strength (Table 1). Stem length was significantly affected by temperature; stems grew $38 \%$ longer at $30 \mathrm{C}$ than at $14 \mathrm{C}$. The additional stem length resulted from additional nodes and longer internodes. Average internode length was $4.7 \mathrm{~cm}$ at $30 \mathrm{C}$ and $4.5 \mathrm{~cm}$ at $14 \mathrm{C}$. The significant quadratic trend for node number was due to the small difference between 14 and $22 \mathrm{C}$, compared with the large difference between 22 and 30C. Critical load (stem strength) is a function of stem length and stem diameter (Goeschl et al., 1966). The decrease in stem length and coincident increase in stem diameter with decreasing temperature resulted in a linear increase in critical load (Table 1).

Reducing PPF produced the opposite effect of decreasing temperature. The decrease in PPF from 695 to $315 \mu \mathrm{mol} \cdot \mathrm{s}^{-1} \cdot \mathrm{m}^{-2}$ resulted in a linear increase in stem length and node number and a linear decrease in stem diameter, number of stems, and stem strength (Table 1). Stem length was also affected by PPF; each $10-\mu \mathrm{mol} \cdot \mathrm{s}^{-1} \cdot \mathrm{m}^{-2}$ reduction in PPF resulted in a $0.5-\mathrm{cm}$ increase in stem length due to an increase in node number and internode length. Average internode lengths were 4.1 and 5.2 $\mathrm{cm}$ for PPF values of 695 and $315 \mu \mathrm{mol} \cdot \mathrm{s}^{-1} \cdot \mathrm{m}^{-2}$, respectively. The number of stems was significantly reduced as PPF decreased but was unaffected by temperature (Table 1), indicating that PPF was more important in stem initiation and development than temperature.

Rate of stem elongation. Stems elongated sigmoidally over time (Fig. 1, upper and lower left). Stem elongation was more rapid the higher the temperature and was most rapid between weeks 1 and 4 for plants grown at 30 and 22C, regardless of PPF. Plants grown at $14 \mathrm{C}$, however, did not elongate rapidly until after week 4, but sustained that rate for an additional 7 to 10 weeks, depending on PPF treatment. The rates of stem elongation during the main phase of growth were determined by fitting linear regressions of stem length over time during the period 0.25 to 0.75 of the interval from the beginning of treatments to flowering (McPherson et al., 1985). Stem elongation rate at $14 \mathrm{C}$ was significantly lower, regardless of PPF treatment, compared with stems grown at 22 or 30C (Fig. 1, lower right). Stems grew slowest on plants under high PPF and fastest under low PPF for all temperatures (Fig. 1, lower right). The increase

Table 1. Effect of temperature and PPF on flowering stem characteristics of Oxypetalum caeruleum. No interactions occurred for any characteristic. The values were recorded at time of first flowering in each treatment.

\begin{tabular}{|c|c|c|c|c|c|}
\hline Variable & $\begin{array}{l}\text { Stem } \\
\text { length } \\
(\mathrm{cm})\end{array}$ & $\begin{array}{r}\text { Stem } \\
\text { diam } \\
(\mathrm{cm})\end{array}$ & $\begin{array}{c}\text { Stems } \\
\text { (no.) }\end{array}$ & $\begin{array}{c}\text { Nodes } \\
\text { per stem } \\
\text { (no.) }\end{array}$ & $\begin{array}{c}\text { Critical } \\
\text { load } \\
\left(\mathrm{mm} \cdot \mathrm{cm}^{-1}\right)\end{array}$ \\
\hline \multicolumn{6}{|c|}{ Temperature $\left({ }^{\circ} \mathrm{C}\right)$} \\
\hline 30 & 62.2 & 29.7 & 2.6 & 13.3 & 0.48 \\
\hline 22 & 50.4 & 30.9 & 2.6 & 10.5 & 0.61 \\
\hline 14 & 45.1 & 35.4 & 2.5 & 10.1 & 0.78 \\
\hline $\mathrm{T}_{\text {linear }}$ & $*$ & $*$ & NS & $*$ & $*$ \\
\hline $\mathrm{T}_{\text {quadratic }}$ & NS & NS & NS & * & NS \\
\hline \multicolumn{6}{|c|}{$\mathrm{PPF}\left(\mu \mathrm{mol} \cdot \mathrm{s}^{-1} \cdot \mathrm{m}^{-2}\right)$} \\
\hline 695 & 43.4 & 33.5 & 3.9 & 10.7 & 0.77 \\
\hline 450 & 54.3 & 32.0 & 2.1 & 11.3 & 0.59 \\
\hline 315 & 62.4 & 30.3 & 1.5 & 12.0 & 0.48 \\
\hline $\mathrm{I}_{\text {linear }}$ & $*$ & $*$ & $*$ & $*$ & $*$ \\
\hline$I_{\text {quadratic }}$ & NS & NS & NS & NS & NS \\
\hline
\end{tabular}



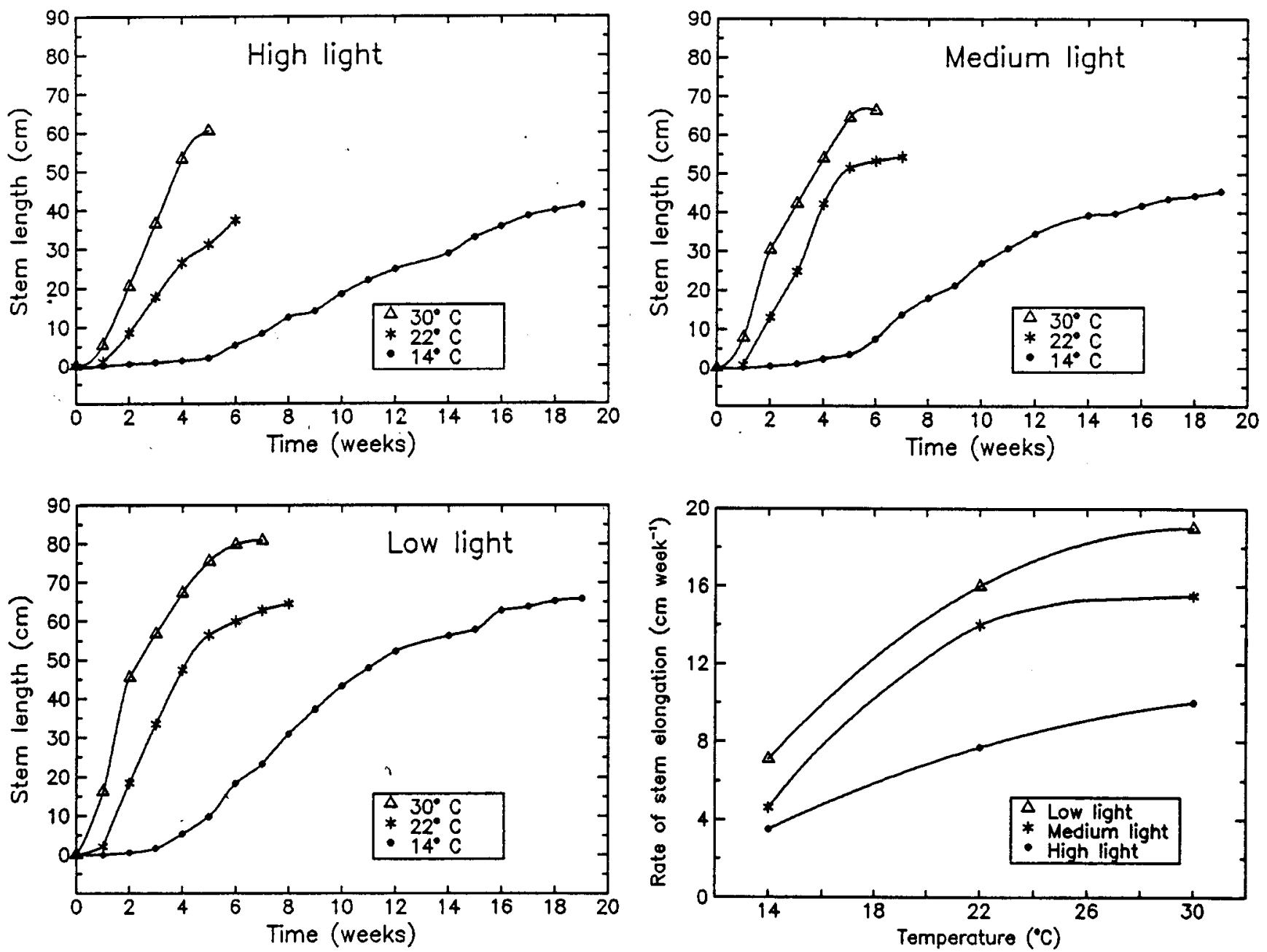

Fig. 1. Influence of PPF and temperature on stem length of Oxypetalum caeruleum. High light $=695 \mu \mathrm{mol} \cdot \mathrm{s}^{-1} \cdot \mathrm{m}^{-2}, \mathrm{medium} \mathrm{light}=450$ $\mu \mathrm{mol} \cdot \mathrm{s}^{-1} \cdot \mathrm{m}^{-2}$, low light $=315 \mu \mathrm{mol} \cdot \mathrm{s}^{-1} \cdot \mathrm{m}^{-2}$. (lower right) Rate of stem elongation.

in stem elongation between 14 and 30C was lower for high PPF (64\%) than for medium (276\%) and low PPF (178\%).

Net photosynthesis. Pn differed significantly for all PPF treatments at 30 and 22C; however, no differences occurred in Pn at $14 \mathrm{C}$, regardless of PPF (Fig. 2). Pn rose between 14 and 22C

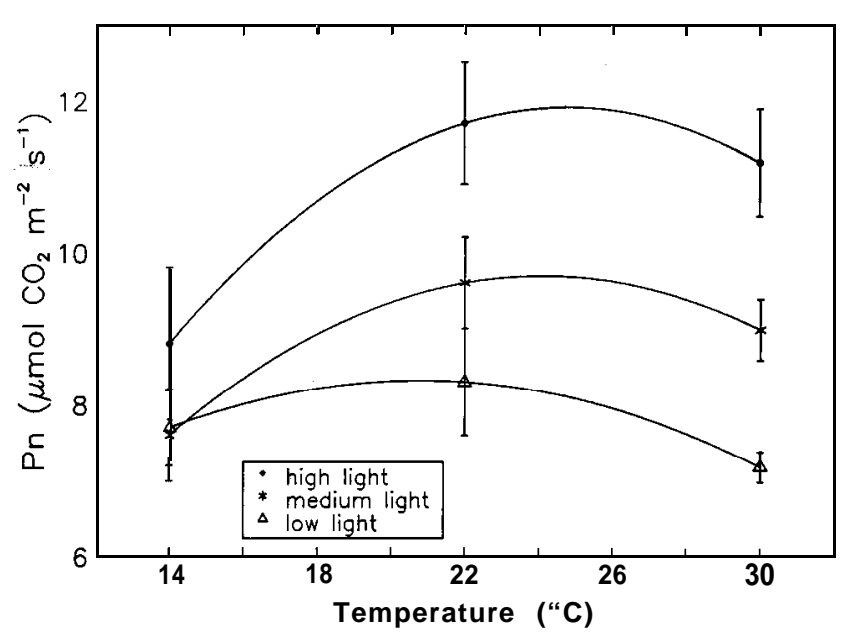

Fig. 2. Influence of PPF and temperature on Pn of Oxypetalum caendeum. Vertical bars represent 1 SE of the mean. and declined between 22 and 30C for all PPF treatments (Fig. 2 ), although an optimum rate may have occurred between 24 and 26C, particularly under high PPF conditions. This response to temperature is similar to that of other $\mathrm{C}_{3}$ plants, where the optimum temperature for photosynthesis is in the 20 to $25 \mathrm{C}$ range (Berry and Bjorkman, 1980). A high rate of photosynthesis is commonly observed in leaves acclimated to high, in contrast to low, PPF conditions (Boardman, 1977). Pn was $80 \%$ saturated at $1045 \mu \mathrm{mol} \cdot \mathrm{s}^{-1} \cdot \mathrm{m}^{-2}$ (Fig. 3), and the apparent photon quantum yield was $=0.020 \mathrm{~mol} \mathrm{CO}_{2} / \mathrm{mol}$ photons. The saturation point was high compared with geraniums (Pelargonium $\mathbf{x}$ hortorum Bailey) and impatiens (Impatiens hybrida) (Armitage and Vines, 1982), but the apparent photon yield was low compared with other dicotyledonous $\mathrm{C}_{3}$ species that have a photon yield (adsorbed light basis) of $0.052 \mathrm{~mol} \mathrm{CO}_{2} / \mathrm{mol}$ photons (Ehleringer and Pearcy, 1983).

Reproductive characteristics. No temperature $\mathbf{x}$ PPF interactions occurred for any reproductive characteristic measured. With the exception of aborted flowers, all criteria measured were far more responsive to changes in temperature than to changes in PPF (Table 2). Time to flowering was delayed as temperature was lowered, especially between 22 and 14C (Table 2 ), indicating that Oxypetalum should not be grown at cool temperatures. Other genera of Asclepiadaceae show similar temperature effects on flowering. Stephanotis has an optimum of 


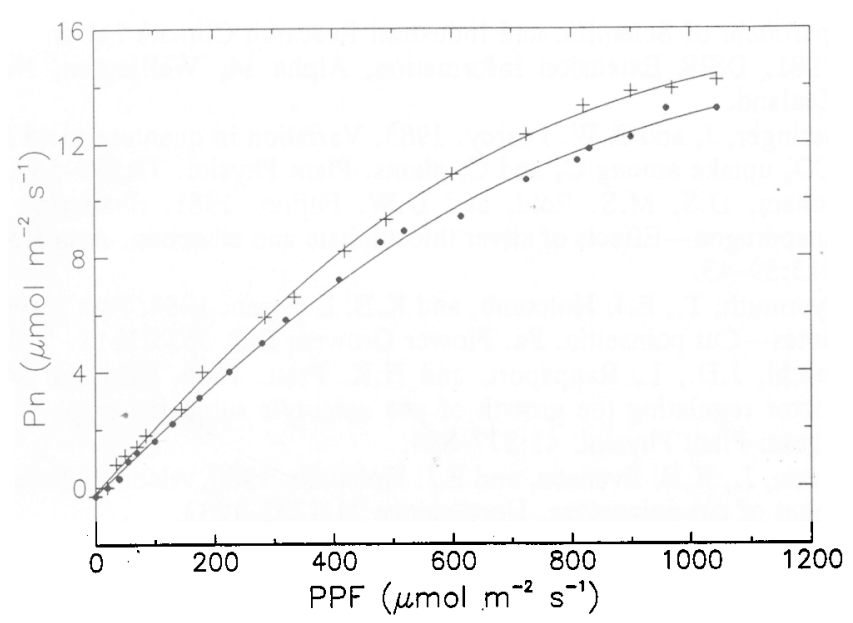

Fig. 3. Effect of PPF on Pn of two single-plant replications of 0xypetalum caendeum grown at $22 \mathrm{C}$ and $\mathrm{PPF}$ of $695 \mu \mathrm{mol} \cdot \mathrm{s}^{-1} \cdot \mathrm{m}^{-2}$. Each data point is the mean of two readings. $+=30 \mathrm{C}$, closed circles $=22 \mathrm{C}$.

Table 2. Effect of temperature and PPF on reproductive characteristics of Oxypetalum caeruleum. No interactions occurred for any characteristic. The values were recorded at time of first flowering in each treatment.

\begin{tabular}{|c|c|c|c|c|c|}
\hline \multirow[b]{2}{*}{ Variable } & \multirow{2}{*}{$\begin{array}{l}\text { Time to } \\
\text { flower } 3 \\
\text { (days) }\end{array}$} & \multicolumn{2}{|c|}{$\begin{array}{c}\text { Flowers per } \\
\text { cyme }\end{array}$} & \multirow{2}{*}{$\begin{array}{c}\text { Aborted } \\
\text { flowers } \\
(\%)\end{array}$} & \multirow{2}{*}{$\begin{array}{c}\text { Flower nodes } \\
\text { to produce } \\
\text { six cymes } \\
\text { (no.) }\end{array}$} \\
\hline & & $\begin{array}{l}3 \text { to } 5 \\
(\%) \\
\end{array}$ & $\begin{array}{l}1 \text { to } 2 \\
(\%)\end{array}$ & & \\
\hline \multicolumn{6}{|c|}{ Temperature $\left({ }^{\circ} \mathrm{C}\right)$} \\
\hline 30 & 32 & 11.4 & 69.0 & 20.1 & 8 \\
\hline 22 & 38 & 70.0 & 26.0 & 3.9 & 6 \\
\hline 14 & 115 & 84.6 & 5.8 & 9.6 & 6 \\
\hline $\mathrm{T}_{\text {linear }}$ & $*$ & $*$ & $*$ & $*$ & * \\
\hline $\mathrm{T}_{\text {quadratic }}$ & $*$ & * & * & $*$ & * \\
\hline \multicolumn{6}{|c|}{$\operatorname{PPF}\left(\mu \mathrm{mol} \cdot \mathrm{s}^{-1} \cdot \mathrm{m}^{-2}\right)$} \\
\hline 695 & 63 & 64.0 & 30.5 & 6.4 & 6 \\
\hline 450 & 59 & 54.4 & 34.9 & 10.7 & 6 \\
\hline 315 & 63 & 47.2 & 34.3 & 18.4 & 7 \\
\hline $\mathrm{I}_{\text {linear }}$ & NS & NS & NS & $*$ & NS \\
\hline $\mathrm{I}_{\text {quadratic }}$ & NS & NS & NS & NS & NS \\
\hline
\end{tabular}

$21 C$ (Kofranek and Criley, 1983) and Hoya has a minimum of $15 C$ for flowering (Post, 1955).

The morphology of the inflorescence was significantly affected by changes in temperature. In Oxypetalum, a well-developed inflorescence consists of cymes with four to five flowers. At low temperature (14C), most cymes consisted of three to five flowers, few had one to two flowers, and few aborted. However, abortion was greater and the proportion of cymes with only one to two flowers were highest at 30C (Table 2). Eight floral nodes were necessary on the panicle to form six cymes on plants grown at 30C. The reduction in cymes as inflorescences increased in length at $30 \mathrm{C}$ resulted in poorly developed flower stems and reduced ornamental value. The quadratic trends shown in the temperature data resulted from the relatively large differences between $30 \mathrm{C}$ and $22 \mathrm{C}$, compared with the differences between 22 and $14 \mathrm{C}$ for all criteria measured (Table 2). These data indicate that $14 \mathrm{C}$ is too cold for commercial flowering and that $30 \mathrm{C}$ results in high rates of flower abortion and poorly developed inflorescences. Temperatures close to $22 \mathrm{C}$ appear optimum for flowering time and flower development. An additional benefit of $22 \mathrm{C}$ was the effect on flower color. At
Table 3. Influence of photoperiod on growth and flowering of $O x y$ petalum caeruleum.

\begin{tabular}{|c|c|c|c|c|c|c|}
\hline \multirow[b]{2}{*}{$\begin{array}{l}\text { Photoperiod } \\
\text { (hr) }\end{array}$} & \multirow[b]{2}{*}{$\begin{array}{c}\text { Stems } \\
\text { (no.) }\end{array}$} & \multirow{2}{*}{$\begin{array}{c}\text { Stem } \\
\text { length } \\
(\mathrm{cm})\end{array}$} & \multirow{2}{*}{$\begin{array}{c}\text { Internode } \\
\text { length } \\
(\mathrm{cm})\end{array}$} & \multirow{2}{*}{$\begin{array}{l}\text { Time to } \\
\text { flower } \\
\text { (days) }\end{array}$} & \multicolumn{2}{|c|}{$\begin{array}{c}\text { Flowers per } \\
\text { cyme }\end{array}$} \\
\hline & & & & & $\begin{array}{c}3 \text { to } 5 \\
(\%)\end{array}$ & $\begin{array}{c}1 \text { to } 2 \\
(\%)\end{array}$ \\
\hline 8 & 1.6 & 40.2 & 3.3 & 33 & 39 & 58 \\
\hline 10 & 1.9 & 47.7 & 3.8 & 38 & 30 & 61 \\
\hline 12 & 2.9 & 50.9 & 5.1 & 35 & 48 & 48 \\
\hline 14 & 3.0 & 58.6 & 5.7 & 41 & 71 & 27 \\
\hline \multirow{2}{*}{$\cdot \begin{array}{l}P_{\text {linear }} \\
P_{\text {quadratic }}\end{array}$} & $*$ & $*$ & $*$ & $*$ & $*$ & $*$ \\
\hline & NS & NS & NS & NS & NS & NS \\
\hline
\end{tabular}

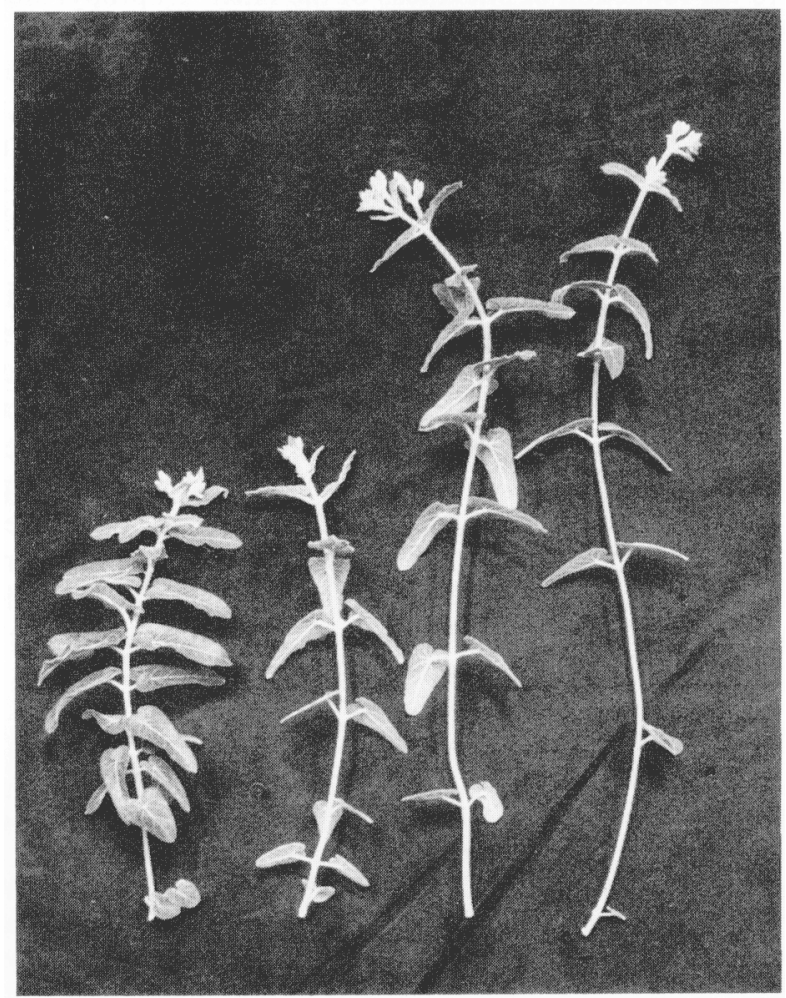

Fig. 4. Influence of photoperiod on stem length and internode length of Oxypetalum caendeum. (left to right) 8-, 10-, 12-, 14-hr photoperiod.

$30 \mathrm{C}$, flowers were blue-pink and tended to fade rapidly, at $22 \mathrm{C}$ flowers were sky blue, and at $14 \mathrm{C}$ they were a muddy, lessattractive blue-mauve.

A trend toward a reduced number of cymes with three to five flowers and an increased number of aborted flowers per cyme occurred under low-PPF conditions (Table 2). In general, however, PPF affected vegetative characteristics more than reproductive parameters (Tables 1 and 2).

\section{Photoperiod}

Most characteristics measured showed a significant linear response to lengthening photoperiod (Table 3). The number of nodes were unaffected by photoperiod (data not shown) and the increase in stem length may be largely attributed to the increase in internode length (Table 3). The longest stems occurred under the longest photoperiods (Fig. 4). The number of flowers per cyme also increased with increasing daylength (Table 3). Stems with more flowers per inflorescence appeared fuller and were of better quality under longer photoperiods. In general, photo- 
periods of 12 and $14 \mathrm{hr}$ resulted in longer stems and higher flower quality than 8 and $10 \mathrm{hr}$, important attributes for cut flower crops. Stem diameter, stem strength, and aborted flowers were not significantly affected due to photoperiod treatments (data not shown).

\section{Postharvest evaluations}

Control stems persisted 8 days, a duration adequate for commercial purposes, but no latex coagulant treatment resulted in significant improvement in vase life. The average vase life for all treatments was 9 days. The use of boiling water did not enhance vase life; although, it was beneficial in handling stems due to the reduction of stickiness of the latex. Isopropyl alcohol caused rapid leaf abscission on some stems, but the damage was inconsistent. This result contrasts with those of Freyermuth et al. (1984), who found beneficial effects of isopropyl alcohol on poinsettia. No differences in vase life occurred due to STS treatments; STS-treated stems (4 or $8 \mathrm{~mm}$ ) abscised slightly later, but flowers still reverted to pink at about the same time as those of control stems.

In summary, both temperature and PPF played a significant role in the growth and flowering of Oxypetalum caendeum. Temperature, however, affected flowering responses and flower morphology more than PPF. Photoperiod had little effect on flowering time but had a significant influence on internode elongation and stem morphology. Growth at 22C and a 12-hr photoperiod resulted in excellent flower color, realistic flowering time, high critical load, and highest quality cymes. Postharvest experiments showed that latex from cut stems was not detrimental to the marketable life of the cut stem and treatments that reduced latex did not result in additional vase life.

\section{Literature Cited}

Armitage, A.M. and H.M. Vines. 1982. Net photosynthesis, diffusive resistance, and chlorophyll content of shade- and sun-tolerant species under different light regimes. HortScience 17:342-343.

Bailey, L.H. ,1951. Manual of cultivated plants. Macmillan, New York.

Berry, J. and O. Bjorkman. 1980. Photosynthetic response and adaptation to temperature in higher plants. Annu. Rev. Plant Physiol. 31:491-543.

Boardman, N.K. 1977. Comparative photosynthesis of sun and shade plants. Annu. Rev. Plant Physiol. 28:355-377.
Department of Scientific and Industrial Research Climate Laboratory. 1981. DSIR Extension Information, Alpha 14, Wellington, New Zealand.

Ehleringer, J. and R.W. Pearcy. 1983. Variation in quantum yield for $\mathrm{CO}$, uptake among $\mathrm{C}_{3}$ and $\mathrm{C}_{4}$ plants. Plant Physiol. 73:555-559.

Farnham, D.S, M.S. Reid, and D.W. Fujino. 1981. Shattering of snapdragon-Effects of silver thiosulphate and ethephon. Acts Hort. 113:39-43.

Freyermuth, T., E.J. Holcomb, and K.B. Evensen. 1984. Post harvest notes-Cut poinsettia. Pa. Flower Growers Bul. 353:11-12.

Goeschl, J. D., L. Rappaport, and H.K. Pratt. 1966. Ethylene as a factor regulating the growth of pea epicotyls subjected to physical stress. Plant Physiol. 41:877-884.

Gordon, J., K.B. Evensen, and E.J. Holcomb. 1986. Alcohol pretreatment of cut poinsettias. HortScience 21: 1232-1233.

Halevy, A.H. and S. Mayak. 1981. Senescence and postharvest physiology of, cut flowers-Part 2, p. 59-143. In: J. Janick (cd.). Horticultural reviews. vol. 3. AVI, Westport, Corm.

Hoagland, D.R. and D.I. Arnon. 1938. The water-culture method for growing plants without soil. Univ. of California Agr. Expt. Sta. Circ. 437.

Kofranek, A. and R.A. Criley. 1983. Photoperiod and temperature effects on Stephanotis flowering. Acts Hort, 147:211-218.

Lyons, R.E. 1985. Asclepias tuberosa, p. 22-28. In: A.H. Halevy (cd.). Handbook of flowering. vol. V. CRC Press, Boca Raton, Fla.

Lyons, R.E. and J.N. Booze. 1983. Effect of photoperiod on first year growth of 2 Asclepias species. HortScience 18:575. (Abstr.)

McPherson, H. G., I.J. Warrington, and H.L. Turnbull. 1985. The effects of temperature and daylength on the rate of development of Pigeonpea. Ann. Bet. 56:597-611.

Post, K. 1955, Florist crop production and marketing. Orange Judd, New York.

Reid, M.S. and A.M. Kofranek. 1980. Recommendations for standardized vase life evaluations. Acts Hort. 113:171-173.

Salinger, J.P. 1985. Commercial flower growing. Butterworths Horticultural Books, Wellington, New Zealand.

Stirling, W.F. 1950. Boiling water keeps iceland poppy fresh. Grower 34:1059.

Systems, W. 1966. De houdbaarheid van poinsettia. Vakblad voor de bloemisterij. 20:301.

Veen, H. and S.C. van de Geijen. 1978. Mobility and ionic form of silver as related to longevity of cut carnations. Planta 140:93-96.

Warrington, I.J. and E.T. Kanemasu. 1983. Corn growth response to temperature and photoperiod. 11. Leaf initiation and leaf appearance rates. Agron. J. 75:755-761. 